\title{
Effects of Buformin on the Metabolism of the Isolated Haemoglobin-Free Perfused Hindlimb of Normal Rats*
}

\author{
P. Strohfeldt, H. Kett1, U. Obermaier, K. F. Weinges \\ Department of Internal Medicine, University of Saarland, Homburg/S., Germany
}

Received: May 21, 1974, and in revised form: March 3, 1975

\begin{abstract}
Summary. Using the isolated, haemoglobin-free, perfused resting hindlimb of normal rats buformin neither had a direct insulin-like effect on glucose uptake by muscle tissue nor potentiated the effect of insulin on glucose uptake after oral pretreatment for one or several days with low and high doses ( $30 \mathrm{mg}-350 \mathrm{mg} / \mathrm{kg}$ ). Effects on glycogenolysis could not be detected. Glycerol release was inhibited after several days of pretreatment with low and high doses of buformin. The
\end{abstract}

utilization of added oleate was also partly inhibited. The level of energy rich phosphates in the muscle tissue and oxygen consumption were not affected under any of the conditions used in these experiments.

Key words: Buformin, muscle metabolism, isolated perfused hindlimb of the rat.
The mode of action of the biguanides is still under discussion. In recent studies from this laboratory concerning the effect of buformin on muscle metabolism we observed an increased glycogen content and a high rate of radioglucose incorporation into the glycogen of the diaphragm of normal rats in vivo after a long term oral administration of buformin $-150-175$ $\mathrm{mg} / \mathrm{kg}-[12]$. Similar results were reported with the perfused rat heart [15] and in in vivo experiments [11]. In order to investigate a direct action of buformin on glucose utilization in skeletal muscle, the isolated perfused hindlimb of the rat was used as a suitable model for metabolic studies [13, 14]. In this study we report the effect of low and high doses of buformin, administered orally for one or several days, on the metabolism of the perfused resting hindlimb of normal rats.

\section{Materials and Methods}

Male, fed Sprague-Dawley rats weighing $160-$ $240 \mathrm{~g}$ were used. Buformin (kindly supplied by the Chemie Grünenthal GmbH, Stolberg, Rhld., Germany) was dissolved in physiological saline (solutions of 5 and 10 per cent respectively) and administered daily via a stomach tube. The doses ranged from 30 to $350 \mathrm{mg} / \mathrm{kg}$. The control animals received physiological saline. The perfusion lasted for $1 \mathrm{~h}$ and started $2.5 \mathrm{~h}$ after the last drug administration. The perfusion technique, apparatus, synthetic medium and analytical

* Supported by a grant of the Deutsche Forschungsgemeinschaft methods used have been reported in detail elsewhere $[13,14]$.

In addition, the standard medium contained oleate (1 mM, ac.ol. E. Merck, Darmstadt, Germany). Oleic acid was added as an emulsion $[9,10]$. Free fatty acids (FFA) were determined by the method of Dole and Meinertz [8]. In the perfusion with insulin (crystalline bovine insulin, Hoechst AG, Frankfurt/M., Germany), the hormone was added at the beginning of the perfusion period in a concentration of $100 \mu \mathrm{U} /$ $\mathrm{ml}$ medium. The Wilcoxon test was used for statistical analysis.

\section{Results}

The basal glucose uptake was not increased by buformin (Table 1). When the glucose uptake was stimulated by submaximal concentrations of insulin, the glucose uptake significantly decreased after prior oral administration of $3-5 \times 175 \mathrm{mg}$ buformin $/ \mathrm{kg}$ (Table 2). The lactate production did not increase significantly. Glycogenolysis could not be detected with or without insulin in the medium.

The glycerol release was lowered after several days of pretreatment with low and high doses of buformin, regardless of the addition of insulin (Tables 1 and 2). The decrease of the concentration of oleate in the medium was less with low and high doses of buformin, but inconsistently (Tables 1 and 2). The content of the energy-rich phosphates in the muscle tissue after perfusion was unaffected under all conditions, as was the oxygen consumption (control values: 
ATP $7.8 \pm 0.3 \mu \mathrm{mol} / \mathrm{g}$, creatine phosphate: $20.0 \pm 1.5$ $\mu \mathrm{mol} / \mathrm{g}$, oxygen consumption: $27.0 \pm 0.8 \mu \mathrm{mol} / \mathrm{g} \times \mathrm{h}$ ).

\section{Discussion}

In the present study, buformin did not increase basal or insulin stimulated glucose uptake of the perfused hindlimb of normal rats after oral pretreatment for one or several days. In contrast, after the administration of $3-5 \times 175 \mathrm{mg} / \mathrm{kg}$ buformin insulin stimulated glucose uptake decreased significantly. This is in contrast with the findings of most of the authors working with the isolated diaphragm (for a review see 1). Similar results were observed in the perfused rat heart [15]. In this study, phenformin was added to the medium at concentrations ranging from 0 to $250 \mu \mathrm{g} / \mathrm{ml}$. A slightly increased glucose uptake occurred only with 40 and $50 \mu \mathrm{g} / \mathrm{ml}$. However, perfused hearts from rats starved for 48 hours showed a decreased glucose uptake with $50 \mu \mathrm{g} / \mathrm{ml}$ phenformin in the medium. Using the forearm method a decreased glucose utilization was also observed in normal human subjects after oral pretreatment with phenformin for 3 days [7]. With the same model biguanides increased

Table 1. Effect of buformin on the metabolism of the perfused hindlimb of normal rats after oral pretreatment for one or several days. The standard medium contained $10 \mathrm{mM}$ glucose, $1 \mathrm{mM}$ lactate, $0.15 \mathrm{mM}$ pyruvate, and $1 \mathrm{mM}$ oleate. The glycogen content of the muscle tissue was determined at the end of the perfusion period. Results are expressed as $\bar{X} \pm S_{\bar{X}}$, the numbers of observations in parentheses

\begin{tabular}{llllll}
\hline pretreatment & $\begin{array}{l}\text { Glucose } \\
\text { uptake } \\
\mu \mathrm{mol} / \mathrm{g} \times \mathrm{h}\end{array}$ & $\begin{array}{l}\text { Lactate } \\
\text { production } \\
\mu \mathrm{mol} / \mathrm{g} \times \mathrm{h}\end{array}$ & $\begin{array}{l}\text { Glycogen } \\
\text { content } \\
\mu \mathrm{mol} / \mathrm{g}\end{array}$ & $\begin{array}{l}\text { Glycerol } \\
\text { release } \\
\mu \mathrm{mol} / \mathrm{g} \times \mathrm{h}\end{array}$ & $\begin{array}{l}\text { FFA } \\
\text { uptake } \\
\mu \mathrm{mol} / \mathrm{g} \times \mathrm{h}\end{array}$ \\
\hline $\begin{array}{l}8.4 \pm 0.3 \\
\text { control }\end{array}$ & $\begin{array}{l}8.3 \pm 0.7 \\
(12)\end{array}$ & $\begin{array}{l}36.3 \pm 1.8 \\
(11)\end{array}$ & $\begin{array}{l}0.31 \pm 0.01 \\
(12)\end{array}$ & $\begin{array}{l}0.64 \pm 0.05 \\
(12)\end{array}$ \\
\hline $\begin{array}{l}1 \times 100 \mathrm{mg} / \mathrm{kg} \\
\text { buformin }\end{array}$ & $7.1 \pm 0.6$ & $7.5 \pm 1.3$ & $36.8 \pm 1.6$ & $0.31 \pm 0.05$ & $0.41 \pm 0.08^{\mathrm{a}}$ \\
\hline $1 \times 250 \mathrm{mg} / \mathrm{kg}$ & $9.6 \pm 0.9$ & $9.6 \times 0.5$ & $46.7 \pm 4.5$ & $0.34 \pm 0.02$ & $0.71 \pm 0.06$ \\
buformin & $(4)$ & $(4)$ & $(4)$ & $(4)$ & $(4)$ \\
\hline $\begin{array}{l}1 \times 350 \mathrm{mg} / \mathrm{kg} \\
\text { buformin }\end{array}$ & $7.6 \pm 0.6$ & $9.1 \pm 0.8$ & $53.9 \pm 4.6^{\mathrm{a}}$ & $0.25 \pm 0.006$ & $0.55 \pm 0.05$ \\
\hline $\begin{array}{l}7 \times 100 \mathrm{mg} / \mathrm{kg} \\
\text { buformin }\end{array}$ & $6.9 \pm 0.5$ & $8.3 \pm 0.5$ & $40.6 \pm 3.5$ & $0.20 \pm 0.02^{\mathrm{a}}$ & $0.26 \pm 0.06^{\mathrm{a}}$ \\
\hline $\begin{array}{l}3-5 \times 175 \mathrm{mg} / \mathrm{kg} \\
\text { buformin }\end{array}$ & $7.5 \pm 0.2$ & $10.5 \pm 0.7$ & $46.3 \pm 9.7$ & $0.21 \pm 0.03$ & $0.46 \pm 0.02^{\mathrm{a}}$ \\
\hline
\end{tabular}

Table 2. Effect of buformin on the metabolism of the perfused hindlimb of normal rats after oral pretreatment for one or several days in the presence of insulin $(100 \mu \mathrm{U} / \mathrm{ml})$. For further details see legend Table 1

\begin{tabular}{|c|c|c|c|c|c|}
\hline pretreatment & $\begin{array}{l}\text { Glucose } \\
\text { uptake } \\
\mu \mathrm{mol} / \mathrm{g} \times \mathrm{h}\end{array}$ & $\begin{array}{l}\text { Lactate } \\
\text { production } \\
\mu \mathrm{mol} / \mathrm{g} \times \mathrm{h}\end{array}$ & $\begin{array}{l}\text { Glycogen } \\
\text { content } \\
\mu \mathrm{mol} / \mathrm{g}\end{array}$ & $\begin{array}{l}\text { Glycerol } \\
\text { release } \\
\mu \mathrm{mol} / \mathrm{g} \times \mathrm{h}\end{array}$ & $\begin{array}{l}\text { FFA } \\
\text { uptake } \\
\mu \mathrm{mol} / \mathrm{g} \times \mathrm{h}\end{array}$ \\
\hline $\begin{array}{l}100 \mu \mathrm{U} \text { insulin } \\
\text { ml medium }\end{array}$ & $\begin{array}{l}13.7 \pm 0.6 \\
(5)\end{array}$ & $\begin{array}{l}11.5 \pm 0.7 \\
(5)\end{array}$ & $\begin{array}{l}39.8 \pm 3.7 \\
(5)\end{array}$ & $\begin{array}{l}0.36 \pm 0.02 \\
(5)\end{array}$ & $\begin{array}{l}0.90 \pm 0.02 \\
\text { (5) }\end{array}$ \\
\hline $\begin{array}{l}7 \times 30 \mathrm{mg} / \mathrm{kg} \\
\text { buformin }+ \\
100 \mu \mathrm{U} \text { insulin } / \mathrm{ml}\end{array}$ & $\begin{array}{l}11.4 \pm 0.8 \\
(5)\end{array}$ & $\begin{array}{l}10.2 \pm 0.7 \\
(5)\end{array}$ & $\begin{array}{l}46.9 \pm 2.1 \\
(3)\end{array}$ & $\begin{array}{l}0.27 \pm 0.006^{\mathrm{a}} \\
(5)\end{array}$ & $\begin{array}{l}0.76 \pm 0.08 \\
(5)\end{array}$ \\
\hline $\begin{array}{l}7 \times 100 \mathrm{mg} / \mathrm{kg} \\
\text { buformin }+ \\
100 \mu \mathrm{U} \text { insulin } / \mathrm{ml}\end{array}$ & $\begin{array}{l}12.4 \pm 0.6 \\
(7)\end{array}$ & $\begin{array}{l}9.1 \pm 0.6^{\mathrm{a}} \\
(7)\end{array}$ & $\begin{array}{l}45.6 \pm 3.9 \\
(7)\end{array}$ & $\begin{array}{l}0.16 \pm 0.02^{\mathrm{a}} \\
(7)\end{array}$ & $\begin{array}{l}0.88 \pm 0.06 \\
(7)\end{array}$ \\
\hline $\begin{array}{l}3-5 \times 175 \mathrm{mg} / \mathrm{kg} \\
\text { buformin }+ \\
100 \mu U \text { insulin } / \mathrm{ml}\end{array}$ & $\begin{array}{l}10.8 \pm 0.7^{\mathrm{a}} \\
(7)\end{array}$ & $\begin{array}{l}11.2 \pm 0.6 \\
(7)\end{array}$ & $\begin{array}{l}52.2 \pm 4.0 \\
(3)\end{array}$ & $\begin{array}{l}0.25 \pm 0.02^{a} \\
\text { (7) }\end{array}$ & $\begin{array}{l}0.68 \pm 0.02^{\mathrm{a}} \\
\text { (7) }\end{array}$ \\
\hline
\end{tabular}

a significantly different from control $(p<0.05)$ 
glucose utilization and the effect of insulin in diabetic subjects $[2,3,4]$.

In our experiments, the glycogen content of the hindlimb muscle at the end of the perfusion was not affected when compared to the control perfusions. It is not possible to establish glucose balances in our experiments because there was no information available on the glycogen content of the perfused muscle at the beginning of the perfusion period. Using the isolated diaphragm, a glycogen breakdown was always observed in the presence of biguanides (for a review see 1$)$. With in vivo experiments (11, for a review see 1) or with the perfused rat heart [15] the glycogen changes were small or there was an elevation of glycogen content under the influence of biguanides. We therefore assume that the increased glucose uptake and glycogen breakdown found with the isolated diaphragm under the influence of biguanides results rather from the unfavourable model than from the biguanides. Since no similar investigations have been published concerning the effect of biguanides on muscle metabolism of the isolated perfused resting hindlimb of normal rats, it is difficult to compare our data with those coming from other in vitro and in vivo experimental models.

The antilipolytic action we observed is known from in vitro studies with adipose tissue (for a review see 1). The utilization of the added oleate was partly inhibited after pretreatment with buformin. It cannot be decided from our experiments whether this effect is caused by a decreased activation of the fatty acid or by an inhibition of its oxidation. With isolated guinea pig heart mitochondria a decreased oxidation of acyl-CoA derivatives of long chain fatty acids and of palmitylcarnitine was observed under the influence of phenformin $[5,6]$. Similar results were obtained in in vivo experiments after several days of pretreatment of normal rats with phenformin using an intravenous injection of 14C-1-palmitate [11].

The level of energy-rich phosphates was not affected under all conditions. In the perfused rat heart no effect on the intracellular ATP concentration was found with $50 \mu \mathrm{g} / \mathrm{ml}$ phenformin after $30 \mathrm{~min}$ of perfusion; after $60 \mathrm{~min}$ perfusion, however, a significant decrease was observed [15]. Buformin had no effect on the general oxygen consumption. It is not possible from our data to calculate oxidation rates for the substrates employed.

We conclude from our observations that buformin after oral pretreatment for one or several days with low and high doses has neither a direct insulin-like effect on glucose uptake by the muscle tissue of normal rats nor potentiates the effect of insulin on glucose uptake.

\section{References}

1. Beckmann, R.: Biguanide (Experimenteller Teil), In: Hdbch. der experimentellen Pharmakologie, (eds. O. Eichler, A. Farah, H. Herken, A. D. Welch. Bd. XXIX, ed. H. Maske), p. 489, p. 499. Berlin-Heidelberg-New York: Springer Verlag 1971

2. Butterfield, W. J. H., Fry, I. K., Whichelow, M. J.: The hypoglycaemic action of phenformin. Studies in diabetics after short-term therapy. Lancet 1961 II, 563-567

3. Butterfield, W. J. H., Whichelow, M. J.: Effect of diet, sulphonylureas, and phenformin on peripheral glucose uptake in diabetes and obesity. Lancet $1968 \mathrm{II}, 785-788$

4. Butterfield, W. J. H.: The effects of phenformin on peripheral glucose utilization and insulin action in obesity and diabetes mellitus. Ann. N.Y. Acad. Sci. 148, 724-733 (1968)

5. Davidoff, F.: Effects of guanidine derivatives on mitochondrial function. I. Phenethylbiguanide inhibition of respiration in mitochondria from guinea pig and rat tissues. J. clin. Invest. 47, 2331-2343 (1968)

6. Davidoff, F.: Effects of guanidine derivatives on mitochondrial function. II. Reversal of guanidine-derivative inhibition by free fatty acids. J. clin. Invest. 47, 2344-2358 (1968)

7. Dietze, G., Wicklmayer, M., Braun, S., Hepp, K. D., Mehnert, H.: Untersuchungen zur Wirkung von Biguaniden am Gesunden. Die Glukoseutilisation des Muskels unter dem Einfluß von Phenformin. Vortrag 80. Tagung Deutsch. Ges. Inn. Med., Wiesbaden, 1974. Abstr. 288

8. Dole, V. P., Meinertz, H.: Microdetermination of longchain fatty acids in plasma and tissues. J. biol. Chem. 235, $2595-2599(1960)$

9. Fröblich, J., Wieland, O.: Different actions of glucagon and fatty acids on gluconeogenesis from lactate in the perfused rat liver. Horm. Metab. Res. 4, 171-175 (1972)

10. Löffler, G., Matschinsky, F., Wieland, O.: Über dem Mechanismus der gesteigerten Ketonkörperbildung. II. Redox Status des DPN der isolierten Rattenleber bei Durchströmung mit Fettsäuren. Biochem. Z. 342, 76-84 (1975)

11. Losert, W., Schillinger, E., Kraaz, W., Loge, D., Jahn, P.: Tierexperimentelle Untersuchungen zur Wirkungsweise der Biguanide. 3. Mitteilung: Versuche mit nicht hypoglykämisch wirkenden Biguaniddosen. Drug. Res. 22, $1540-1552$ (1972)

12. Strohfeldt, P., Ehrhardt, M., Kettl, H., Weinges, K. F.: Experimental studies on the glycogen content and the incorporation of radioglucose into the glycogen of the diaphragm of rats after initial and short term administration of buformin. Diabetologia 8, 37-40 (1972)

13. Strohfeldt, P.: Das isoliert perfundierte Hinterbein der Ratte als Modell zur Untersuchung des Muskelstoffwechsels. Res. exp. Med. 162, 7-16 (1973)

14. Strohfeldt, P., Kettl, H., Weinges, K. F.: Perfusion of the isolated rat hindlimb with a synthetic medium. Horm. Metab. Res. 6, 167-168 (1974)

15. Williamson, J. R., Walker, R. S., Renold, A. E.: Metabolic effects of phenethylbiguanide (DBI) on the isolated perfused rat heart. Metabolism 12, 1141-1152 (1963)

\author{
Dr. P. Strohfeldt \\ Medizinische Univ.-Klinik \\ und Poliklinik \\ D-665 Homburg/Saar \\ Germany
}

